\title{
Is the CJEU Discriminating in Age Discrimination Cases?
}

\author{
Beryl ter Haar*
}

\section{Abstract}

Claims have been made that the Court of Justice of the European Union (CJEU) is more lenient in accepting age discriminating measures affecting older people than in those affecting younger people. This claim is scrutinised in this article, first, by making a quantitative analysis of the outcomes of the CJEU's case law on age discrimination cases, followed by a qualitative analysis of the line of reasoning of the CJEU in these cases and concluding with an evaluation of the Court's reasoning against three theoretical approaches that set the context for the assessment of the justifications of age discrimination: complete life view, fair innings argument and typical anti-discrimination approach. The analysis shows that the CJEU relies more on the complete life view approach to assess measures discriminating old people and the fair innings argument approach to assess measures discriminating young people. This results in old people often having to accept disadvantageous measures and young workers often being treated more favourably.

Keywords: age discrimination, old people, young people, complete life view, fair innings argument

\section{Introduction}

Age is as discrimination ground included in Directive 2000/78/EC, establishing a general framework for equal treatment in employment and occupation (further referred to as Framework Equality Directive or FED). Approximately twenty years on, there exists a substantive body of case law (I identified forty-eight cases for this article) from the Court of Justice of the European Union (CJEU). The vast majority of these cases concern older workers, whereas a much smaller number of cases deal with discrimination younger workers. Over the course of time the impression has grown that the CJEU is more lenient in justifying measures that are disadvantageous to older workers compared with measures nega-

\footnotetext{
Beryl ter Haar is assistant professor and academic coordinator of the Advanced LL.M. Global and European Labour Law at Leiden University and visiting professor at the University of Warsaw.

1. E.g. B.P. ter Haar and M. Rönnmar, Intergenerational Bargaining, EU Age Discrimination and EU Policies - An Integrated Analysis, Report for the project 'Intergenerational Bargaining Towards Integrated Bargaining for Younger and Older Workers in EU Countries (2014), at 25; and T. Gyulavári, 'Age Discrimination: Recent Case Law of the European Court of Justice', 14 ERA Forum 377 (2013)
}

tively affecting younger workers. ${ }^{1}$ This study attempts to find out whether this impression is correct.

Towards this end I elaborate in Section 2 on age as discrimination ground and its regulation in EU law, including a discussion of theoretical approaches, i.e. complete life view and fair innings argument, underpinning the evaluation of age discrimination cases. Section 3 holds a quantitative analysis assessing how many cases the CJEU found to be precluded or not by the FED and whether there is a difference in numbers between the four age categories (old, young, middle-aged and other). If there is a significant difference between the age categories old and young, this could be a first indication that the Court might indeed be discriminatory. In Section 4 a qualitative analysis is made of the content of the cases identified in Section 3. The aim of the analysis is to identify the main reasons for the CJEU to conclude that a measure would be precluded by EU law or not. The analysis is done per age category. In Section 5 the outcome of the qualitative analysis is evaluated against the background of the theoretical approaches presented in Section 2 in order to determine whether the CJEU is indeed biased in its case law and has hence at least created the image of being discriminatory in age discrimination cases.

\section{Age as Discrimination Ground in EU Law}

When the Framework Equality Directive 2000/78/EC ( FED) was adopted, it was not so evident to include age as discrimination ground as it currently seems to be. Distinctions made on the grounds of age are routinely accepted as dictated by common sense. For example, it is generally accepted that there is a minimum age for driving a car, drinking alcohol, voting, acting as a judge, etc. $^{2}$ Likewise, it seems commonly accepted that age limits are set to certain activities such as sports, modelling, etc. as well as certain jobs that require good physical health and strength, up to the fact that at a certain age working life ends. Furthermore, unlike discrimination on grounds such as gender, sexual orientation and race, age is a passing personal characteristic, giving rise to the argument for a more lax protection against

2. M. Sargant, 'Young People and Age Discrimination', 2 E-Journal of International and Comparative Labour Studies 1 (2013). 
discrimination on the grounds of age. The acceptance of age as a passing personal characteristic has consequences for how the discriminatory measures are being evaluated. This is not only reflected in the positive law of the FED, which allows for general justifications based on labour market-related issues, ${ }^{3}$ but also in theoretical approaches.

Two dominant theories in this context are: the complete life view and the fair innings argument. ${ }^{4}$ Both have the commonality that equality between individuals on the grounds of age should not be assessed at one particular moment in time (only) but across a whole lifetime (of work). In particular, McKerlie defined the complete life view in the following terms: '[D]ifferent people's share of resources, or welfare, should be equal when we consider the amounts of those things that they receive over the complete course of their lives. ${ }^{5}$ This means that there will be no discrimination if over the course of a lifetime everyone is eligible for the same benefits and subjected to the same burdens. ${ }^{6}$ Therefore, it is acceptable or even necessary to accept less favourable treatment today, e.g. mandatory retirement or lower wage at the beginning of a career, which might be compensated by more favourable treatment received in the past or to be received in the future. The fair innings argument claims that sometimes we should discriminate on the grounds of age 'to avoid inequality or to achieve substantive equality between generations'. ${ }^{7}$ Effectively, this view favours a positive discrimination approach to ensure that the younger generation will get the same opportunities as the older generation has had. If, at a certain moment in time, both age groups (young and old) were treated the same, this may result in a permanent disadvantage to younger workers compared with the older workers who have lived and worked longer and, as such, have already acquired advantages the young could not yet. ${ }^{8}$

Both these approaches have been critiqued for falling short on certain aspects. One of these aspects is the fact that both approaches are based on a form of distributive inequality over the course of time; however, there are forms of age discrimination that may harm the dignity of a human being or a person's autonomy. ${ }^{9}$ This can particularly be the case when the age distinction is based on stereotypes. ${ }^{10}$ Therefore arguments have been made for a multidimensional approach that takes into account 'the full range of wrongs and harms potentially caused

Recital 25 preamble and Art. 6 FED

Cf. R. Horton, 'Justifying Age Discrimination in the EU', in U. Belavusau and K. Henrard (eds.), EU Anti-Discrimination Law Beyond Gender (2018) 273, at 277-278.

5. D. McKerlie, 'Equality and Time', 99 Ethics 475 (1989).

6. Horton, above n. 4, at 277.

7. Ibid.

8. Ibid

9. Horton, above n. 4, at 279. See also: S. Fredman, Discrimination Law (2011); and B. Hepple, 'Age Discrimination in Employment: Implementing the Framework Directive 2000/78/EC', in S. Fredman and S. Spencer (eds.), Age as an Equality Issue: Legal and Policy Perspectives (2003)

10. Horton, above n. 4, at 283. by differences in treatment because of age'. ${ }^{11}$ In her study about how the CJEU justifies age discrimination, Horton could identify neither a clear preference of the court for one of the approaches, nor a consequent full account of all the wrongs and harms caused by the discriminatory measure. ${ }^{12}$ However, the three approaches, namely complete life view, fair innings argument and the typical anti-discrimination approach, can serve to clarify how the CJEU got its image that it is more lenient in accepting less favourable treatment of older workers and more strict in protecting young workers from age discrimination. In very general terms it could be stated that when the CJEU follows a complete life view approach both age groups have to accept disadvantageous treatments at times, whereas the fair innings argument would justify younger people being treated more favourably sometimes in order to create better opportunities for them that older workers already (could have) had. When more measures under the complete life view are accepted that negatively affect older workers than younger workers and when there are more measures under the fair innings argument that positively affect younger workers to the detriment of older workers, the overall picture is that younger workers are treated more favourably than older workers. This would confirm the image of the CJEU being discriminatory in age discrimination cases.

To find out what the CJEU is actually doing, a combination of qualitative and quantitative research methods is applied. First, an inventory is made of all the cases dealing with age discrimination. These are then ordered by age category, subject of the measure and whether the CJEU found that it would be precluded or not precluded by the FED. This will give a first impression of whether the CJEU precludes more measures that are disadvantageous to young people than to older people. Following this quantitative analysis is a qualitative analysis of the case law based on age category. The focus of the analysis will be on the main reasons for the CJEU to conclude whether a measure should be precluded by the FED or not. This means it will not be an analysis of how the CJEU dealt with cases in relation to the positive law of the FED. The analysis of the main reasons for precluding a measure from the FED or not will give an impression of what the underlying theoretical approach could have been. Understanding this will eventually lead to an evaluation of whether the CJEU is discriminating in age discrimination cases.

\section{Quantitative Analysis of Age Discrimination Cases}

Based on Article 18 FED, Member States had until December 2003 to implement the directive, with the option of extending this period by another three years,

11. Ibid., at 280 .

12. Horton, above n. 4. 


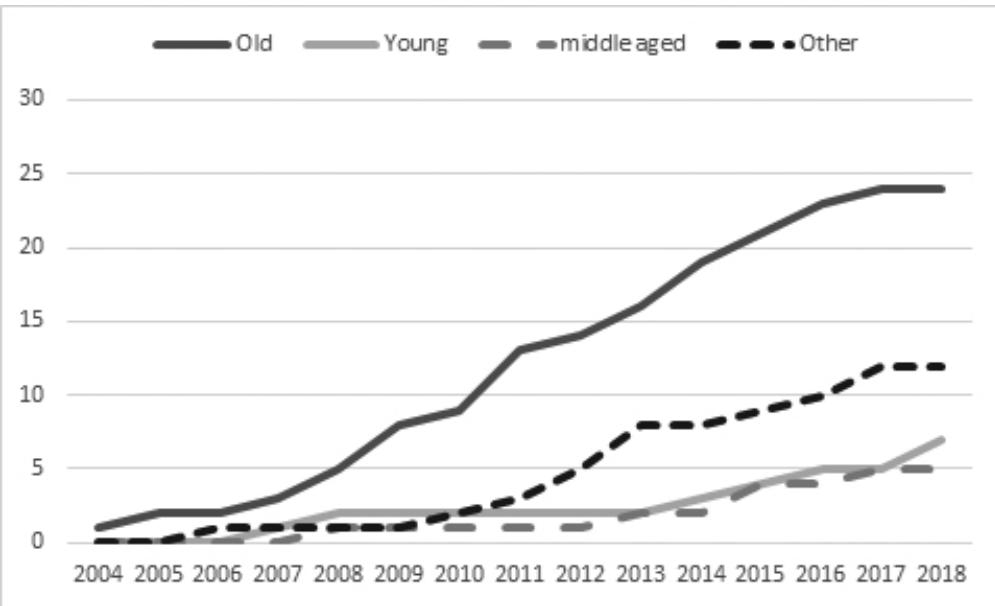

making a total of six years. Consequently, we find the first cases dealing with age discrimination only since $2004^{13}$ and a real increase in the number of cases after 2006, i.e. when the implementation period expired for all the Member States.

A search in Eurlex for cases based on the FED in general results in over seventy cases, more than half of which, forty-eight, deal with age discrimination. ${ }^{14} \mathrm{~A}$ further breakdown of the numbers by different age categories (old, young and middle-aged; and a rest category 'other') reveals that the majority of these cases concern older workers (twenty-four). We also see a slow increase in the number of cases concerning young people (seven)

and merely five cases dealing with issues affecting middle-aged people. A rather surprisingly high number of cases (twelve) deal with issues that cannot be directly linked to a specific age category. The development of these cases over time is shown in Figure 1.

The large number of cases dealing with issues concerning older workers is clearly visible in Figure 1. By far the majority of these cases deal with issues related to retirement (see also Table 1). Cases dealing with issues concerning young people and middle-aged people seem to pick up pace from 2013. The cases in the latter group affect people who are distinguished from a younger group of workers since the divide often lies around the age of thirty or thirty-five; hence the qualification of 'middle-aged'.

The last category of cases, 'other', is remarkably large, with twelve cases. Figure 1 shows a strong increase in cases of this kind after 2011. A brief glance at the content of these cases reveals that a good number of them is actually related to the CJEU's judgment in the case

13. An exception is the case Mangold, which was dealt with before the implementation period had passed. Case 144/04 Werner Mangold v. Rüdiger Helm, [2005] ECR I- 09981.

14. Eurlex search dated 26 October 2019. There are more cases dealing with age discrimination that did not show up in this search since they are not based on the FED. For example, Case 619/18 European Commission v. Republic of Poland ECLI:EU:C:2019:531. Since the main topic of this article is about the CJEU's attitude regarding justifications based on Art. 6 FED, such omissions do not affect this study.
Hütter. ${ }^{15}$ This may be briefly explained as follows: in Hütter the CJEU ruled that a measure excluding work experience gained before the age of eighteen resulted in a difference in treatment between young people in the same age group and was therefore to be interpreted as being precluded by Articles 1, 2 and 6 of the FED. ${ }^{16}$ Following the ruling in Hütter, similar national measures, mainly from Austria and Germany, have been adjusted to end the discriminatory effect they had. In the cases dealing with these measures, questions have been raised as to whether the adjustments have sufficiently neutralised the (effects of the) previously existing discriminatory situation. ${ }^{17}$ Since these cases deal with transitional legislation they cannot be directly linked to a particular age category, and hence the categorisation as 'other'.

In Table 1 the cases are listed by age category and subsequently by the subject of the measures that are challenged and the CJEU's conclusion concerning whether the measure would be precluded or not by the FED. Before discussing the content of Table 1 a few preliminary remarks need to be made. A number of cases that are included in Figure 1 are not included in this table. Werner Fries, ${ }^{18}$ a case rather similar to Prigge, is excluded, because, even though it popped up in Eurlex by searching on the FED, it is actually based on Regulation (EC) No 216/2008, which deals with civil aviation safety in Europe. Case $C^{19}$ is also not included because the CJEU concluded that the tax measure, which intended to create incentives for older workers to work longer, does not fall within the scope of the FED. Lastly, Garda Síochána $^{20}$ is not included because the CJEU was not asked to determine whether the national measure was discriminatory on grounds of age; instead it was asked

15. Case 88/08 David Hütter v. Technische Universität Graz, [2009] ECR I05325.

16. Ibid., Rec 49

17. For a more elaborate discussion of these cases see section 4.3.

18. Case 190/16 Werner Fries v. Lufthansa CityLine GmbH ECLI:EU:C: 2017:513.

19. Case 122/15 Proceedings brought by C. ECLI:EU:C:2016:391.

20. Case 378/17 The Minister for Justice and Equality and The Commissioner of the Garda Síochána v. Workplace Relations Commission ECLI:EU:C:2018:979. 
Table $1 \quad$ Overviem of topics by age category and outcome of the CFEU's rulings

\begin{tabular}{|c|c|c|c|}
\hline \multirow[t]{2}{*}{ Category } & \multirow[t]{2}{*}{ Topic } & \multicolumn{2}{|l|}{ Rulings CJEU - measure precluded } \\
\hline & & Yes & No \\
\hline \multirow[t]{6}{*}{ Old } & $\begin{array}{l}\text { Mandatory retirement; fixed age for retire- } \\
\text { ment; automatic termination }\end{array}$ & Commission v. Hungary & $\begin{array}{l}\text { Palacios de la Villa; Age Concern; } \\
\text { Petersen; Rosenbladt; Georgiev; } \\
\text { Fuchs \& Köhler; Hörnveldt }\end{array}$ \\
\hline & $\begin{array}{l}\text { Severence payment, etc. when at retirement } \\
\text { age }\end{array}$ & $\begin{array}{l}\text { Ingeniørforeningen i Danmark; } \\
\text { Dansk Jurist; Rasmussen }\end{array}$ & $\begin{array}{l}\text { Odar; Ingeniørforeningen i Danmark } \\
\text { v. Tekniq }\end{array}$ \\
\hline & $\begin{array}{l}\text { Retirement irt physical requirements capabil- } \\
\text { ities }\end{array}$ & Prigge & \\
\hline & $\begin{array}{l}\text { Age-related retirement contributions/limited } \\
\text { entitlements to retirement schemes/other } \\
\text { limitations related to retirement schemes }\end{array}$ & & $\begin{array}{l}\text { HK Denmark; Parris; Kleinsteuber; } \\
\text { Felber }\end{array}$ \\
\hline & $\begin{array}{l}\text { Prohibition combining retirement pension } \\
\text { with other incomes }\end{array}$ & & Florescu; SCMD \\
\hline & Older workers and fixed-term contracts & Mangold & Hubertus \\
\hline \multirow[t]{3}{*}{ Young } & $\begin{array}{l}\text { Age limitation on calculating years of expe- } \\
\text { rience/development of pay grades/salary } \\
\text { reductions }\end{array}$ & Kücükdeveci; Hütter & $\begin{array}{l}\text { Lesar; Escribano Vindel; Horgan and } \\
\text { Keegan }\end{array}$ \\
\hline & $\begin{array}{l}\text { Access to severance/compensation pay- } \\
\text { ments }\end{array}$ & & O. \\
\hline & $\begin{array}{l}\text { Special types of employment contracts limit- } \\
\text { ed to age }\end{array}$ & & Abercrombie \\
\hline \multirow{2}{*}{$\begin{array}{l}\text { Middle- } \\
\text { aged }\end{array}$} & Maximum age for recruitment & Vital Pérez & Wolf; Salaberria Sorondo \\
\hline & Access limitations based on age & & De Lange \\
\hline \multirow[t]{4}{*}{ Other } & $\begin{array}{l}\text { Reclassification measures to correct previ- } \\
\text { ously discriminatory measures/transitional } \\
\text { system to protect established advantages }\end{array}$ & Starjakob; Schmitzer; Leitner & $\begin{array}{l}\text { Hennings and Mai; Specht e.o.; Stoll- } \\
\text { witzer; Unland; Österreichischer } \\
\text { Gewerkschaftsbund }\end{array}$ \\
\hline & Relative age issues & & Bartsch \\
\hline & $\begin{array}{l}\text { non-specific age- and experience-related } \\
\text { issues }\end{array}$ & & Tyrolean Airways; Bowman \\
\hline & Miscellaneous & & Pohl \\
\hline
\end{tabular}

about procedural issues to ensure compliance with the FED.

When reviewing the content of Table 1 what stands out the most is that in all four age categories the CJEU has found that the FED would preclude and not preclude a national measure. Second, regarding many of the widely defined topics the Court finds both measures that can be justified and measures that cannot be justified. This is even the case for the first topic in the category 'old' (i.e. mandatory retirement; fixed age for retirement; automatic termination), albeit that out of eight cases the Court concluded only once that EU law would preclude the national measure, namely Commission v. Hungary. ${ }^{21}$

21. Case 286/12 European Commission v. Hungary ECLI:EU:C:2012:687. As the name of the case suggests, this is not a request for a preliminary ruling by the CJEU, but an action by the Commission against the state
Keeping in mind the focus of this study (is the CJEU ruling more favourable to young people than older people?), it is particularly interesting to note that in the 'young' category the CJEU not only finds measures that would be precluded by EU law, but also those that would not be precluded. Moreover, when we transpose the information of Table 1 from absolute numbers into relative numbers (percentage) of measures to be precluded (yes) and not precluded (no) by the FED, there is hardly any difference between the categories (see Table 2).

Hungary for failing to fulfil its obligations under Arts. 2 and 6 of the FED. For an elaborate discussion of this case, especially its political sensitiveness, see U. Belavusau, 'On Age Discrimination and Beating Dead Dogs: Commission v. Hungary', 50 Common Market Law Review 1145 (2013). 


\begin{tabular}{lcccc}
\hline & \multicolumn{2}{c}{ Absolute numbers } & \multicolumn{2}{c}{ Relative numbers (\%) } \\
\hline Category & Yes & No & Yes & No \\
\hline Old & 6 & 16 & 27 & 73 \\
\hline Young & 2 & 5 & 29 & 71 \\
\hline Middle-aged & 1 & 3 & 25 & 75 \\
\hline Other & 3 & 9 & 25 & 75
\end{tabular}

Given the rather insignificant difference between the age categories, especially between old and young, quantitatively, the proposition that the CJEU is more lenient in accepting discriminatory measures affecting older workers than younger workers seems false. However, these are just numbers. In the next section an analysis of the content of the cases will be made with a focus on the CJEU's reasoning.

\section{Qualitative Analysis of Age Discrimination Cases}

In this section the content of the cases identified in Section 3 will be analysed. The analysis will be done by age category, starting with old, followed by young, other and middle-aged. The results of the analysis will be discussed in Section 5, where they will be evaluated in light of the theoretical approaches described in Section 2.

\subsection{Analysis of the Cases in the Category 'Old'}

As already indicated in Section 3, half of the age discrimination cases (twenty-four out of forty-eight) are found in the category 'old'. Many of the cases in this category have been elaborately discussed in the literature, ${ }^{22}$ especially those dealing with mandatory retirement, ${ }^{23}$ which form the majority of cases in this category. Merely three cases deal with 'just' older workers and

22. E.g. among many others: Gyulavári, above n. 1; M. Schmidt, 'The Principle of Non-discrimination in Respect of Age: Dimensions of the ECJ's Mangold Judgment', 7 German Law Journal 505 (2006); L. Waddington, 'Case C-411/05, Félix Palacios de la Villa v. Cortefi el Servicios SA, Judgment of the Court (Grand Chamber) of 16 October 2007', 45 Common Market Law Review 895 (2008); C. O'Cinneide, 'The Growing Importance of Age Equality', 11 The Equal Rights Review 99 (2013); E. Dewhurst, 'Proportionality Assessments of Mandatory Retirement Measures: Uncovering Guidance for National Courts in Age Discrimination Cases', 45 Industrial Law Journal 60 (2016); and J. Fudge, 'Dignity, Disadvantage, and Age: Putting Constitutional and Fundamental Rights to Work for Older Workers', in A. NumhauserHenning (ed.), Elder Law. Evolving European Perspectives (2017) 55.

23. E.g. Dewhurst, above n. 22; M. Schlachter, 'Mandatory Retirement and Age Discrimination Under EU Law', 27 International Journal of Comparative Labour Law and Industrial Relations 287 (2011); and A. Numhauser-Henning, 'The EU Ban on Age-Discrimination and Older Workers: Potentials and Pitfalls', 29 International Journal of Comparative Labour Law and Industrial Relations 391 (2013). fixed-term contracts. However, the cases Georgiev ${ }^{24}$ and $H_{u b e r t u s^{25}}$ actually also deal with retirement, since they are about national measures that allow for the postponement of the retirement - in Georgiev via a limited number of one-year fixed-term contracts and in Hubertus (as understood by the CJEU ${ }^{26}$ ) by changing one condition in the existing (permanent) employment contract, with half a year per time such as agreed upon by both parties. ${ }^{27}$ The CJEU considered that such measures are not precluded by the FED because they take the entitlement to a pension as an alternative source of income into account. $^{28}$ Additionally, in Georgiev the Court concluded that age was not the only criterion, ${ }^{29}$ and in Hubertus it considered that the measure could not even be considered unfavourable in the sense of Article 2(2) FED. ${ }^{30}$ The third case is Mangold, and even though the implementation period of the FED had not expired yet $^{31}$ the CJEU did consider the content. It concluded that the measure would be precluded by the FED since it was too generic, i.e. neither proportionate nor necessary, to achieve the aim. As such, the measure did not take into account the structure of the labour market or the personal situation of the person in question. ${ }^{32}$

When we focus on the majority of the cases in this category, which deal with retirement, we can see that only five cases were found to be precluded by the FED versus fourteen cases that would not be precluded. With respect to two wide subjects related to retirement, i.e. measures related to access to retirement schemes and measures prohibiting the combination of retirement pensions with other incomes, all national measures challenged were found not to be precluded (see Table 1). In the cases $S C M D^{33}$ and Florescu, ${ }^{34}$ the CJEU concluded

24. Joined cases 250/09 and 268/09 Vasil Ivanov Georgiev v. Tehnicheski universitet - Sofia, filial Plovdiv, [2010] ECR I-11869.

25. Case 46/17 Hubertus John v. Freie Hansestadt Bremen ECLI:EU:C: 2018:131.

26. Ibid., Rec 44-6

27. Ibid., Rec $12-3$

28. Georgiev, above n. 24, Rec 63; Hubertus, above n. 25, Rec 57.

29. Georgiev, above n. 24, $\operatorname{Rec} 62-3$

30. Hubertus, above n. 25, $\operatorname{Rec} 32$

31. Germany had opted for the six-year implementation period

32. Mangold, above n. 13, Rec 65 and 78.

33. Case 262/14, Sindicatul Cadrelor Militare Disponibilizate în rezervă și in retragere $(S C M D)$ v. Ministerul Finanțelor Publice ECLI:EU:C: 2015:336.

34. Case 258/14, Eugenia Florescu and Others v. Casa Judeţeană de Pensii Sibiu and Others ECLI:EU:C:2017:448. 
that the national measure did not fall within the scope of the directive, because the distinction made in the legislation concerns different treatment on grounds not covered by the directive. ${ }^{35}$

In Parris the CJEU dealt with a measure fixing an age for the entitlement to a survivor's pension. Such measures are covered by paragraph 2 of Article 6 FED and therefore do not constitute discrimination on the grounds of age. ${ }^{36}$ In $H K$ Denmark ${ }^{37}$ the CJEU concluded that the measure setting requirements for contributions to a pension scheme could be justified by a legitimate aim. Interestingly, the aim concerned older workers as well as younger workers, namely by relating the height of the contribution to age all workers, young and old, starting to work at Experian should be able to build up reasonable retirement savings, ${ }^{38}$ this the CJEU also found appropriate and necessary. The Court initially seems to reflect in this ruling a fair innings argument but concludes with a complete life view. The aim is for both young and old to be able to build up reasonable retirement savings in the time left till retirement.

Interestingly, in the case Kleinsteuber the CJEU concluded that there is a situation of difference in treatment owing to a combination of measures that 'abstractly' could result in a disadvantage to employees who were 'young when the employment relationship started, the periods of service were short and the ceiling of reckonable years of service was set low'. ${ }^{39}$ Mars (the employer in this case), argued, however, that owing to the application of pro rata temporis, in effect the outcome is not always to the disadvantage of younger workers, because the measure is based on the length of service and not age. $^{40}$ In its final conclusion the CJEU indicates that such a measure would not be precluded by the FED; hence, the Court here shows a clear appreciation of a measure based on the complete life view.

Another group of cases that deserves separate attention concerns entitlements to, among others, severance payments when also eligible for an old-age pension. In total, five cases have been raised with the CJEU. In three of them the Court concluded that the national measure was precluded by the FED, and in two it found that such was not the case (see Table 1). The common issue in these cases is that, in general, severance payments are intended for workers who are expected or have to remain active on the labour market. Such is presumed not to be the case with persons who are (also) eligible for

35. In $S C M D$ the difference in treatment is based on a choice public sector employees can make for earlier retirement (Rec 24-25), and in FloresCu the difference in treatment was based on different public sector professions (Rec 64-5). For an interesting comment on other aspects of the case see Florescu: M. Rocca, 'Florescu: A Memorandum of Understanding Finally Before the Court', 4 International Labor Rights Case Law 98 (2018).

36. Case 443/15 David L. Parris v. Trinity College Dublin and Others ECLI:EU:C:2016:897, Rec 73-76.

37. Case 476/11 HK Danmark acting on behalf of Glennie Kristensen v. Experian A/S ECLI:EU:C:2013:590.

38. Ibid., $\operatorname{Rec} 58$.

39. Case 354/16 Ute Kleinsteuber v. Mars GmbH ECLI:EU:C:2017:539, Rec 56.

40. Ibid., Rec 58 . an old-age pension. Therefore, in general, the (legitimate) aim of national measures precluding persons eligible for an old-age pension from a form of severance payment is to prevent persons claiming a benefit they will not need. The problem with such measures, however, is that they also preclude older workers who wish to remain active on the labour market. ${ }^{41}$ Furthermore, such measures may drive persons into early retirement, resulting in a lower pension scheme compared with when they would have been able to remain on the labour market. ${ }^{42}$ When reviewing the CJEU's rulings in these cases it can be concluded that the Court consistently finds measures not accommodating the interest of the persons who are excluded from a form of severance payment to be precluded by the $\mathrm{FED}^{43}$ and measures taking into account the specific position of the worker as not to be precluded by the FED. ${ }^{44}$ Especially when the national measure, in the long run, results in a reduction of income compared with the same age group that was not affected by the measure, the Court finds the measure unjustifiable. ${ }^{45}$ Here we see again a complete life view approach by the Court.

Most of the cases in this category, however, deal with measures that have linked age to (mandatory) retirement. In only two out of the eight cases did the CJEU find the national measure to be precluded by the FED. In the first case, Prigge, a clause in a collective agreement was challenged that fixed the age of sixty as the limit up to which persons are considered to possess the physical capabilities to (safely) carry out the profession of pilot. ${ }^{46}$ The measure was tested against Articles 2(5), 4(1) and 6 FED but could not be justified by any of them. The age of sixty was considered to be too low to protect public security or the protection of health as provided for by Article 5(2) FED, since internationally it is set at sixty-five. ${ }^{47}$ With respect to Article 4(1) FED, the CJEU considered that possessing certain physical capabilities could be considered a genuine job requirement; however, a strict interpretation thereof results in an assessment of the measure being disproportionate and therefore precluded. ${ }^{48}$ Lastly, with respect to Article 6(1) FED, the CJEU concluded that the aim of the measure (air traffic safety) could not be considered as a legitimate aim recognised by the FED. This is remarka-

41. E.g. Case 515/13, Ingeniørforeningen i Danmark v. Tekniq ECLI:EU:C: 2015:115 (not precluded); and Case 499/08 Ingeniørforeningen i Danmark v. Region Syddanmark, [2010] ECR I-09343 (precluded).

42. E.g. Case 546/11 Dansk Jurist- og Økonomforbund, acting on behalf of Erik Toftgaard v. Indenrigs- og Sundhedsministeriet ECLI:EU:C: 2013:603.

43. Ingeniørforeningen i Danmark $v$ Region Syddanmark, above n. 41, Rec 44-8; Case 441/14 Dansk Industri (DI), acting on behalf of Ajos A/S v. Estate of Karsten Eigil Rasmussen ECLI:EU:C:2016:278, Rec 25-7; and Dansk Jurist, above n. 42, $\operatorname{Rec} 55,62$ and 72.

44. Case 152/11, Johann Odar v. Baxter Deutschland GmbH ECLI:EU:C: 2012:772, Rec 48 and 53; Ingeniørforeningen i Danmark v. Tekniq, above n. 41, Rec 27 (not unreasonable) and 37-9.

45. E.g. Ingeniørforeningen i Danmark, above n. 41, Rec 46

46. Case 447/09 Reinhard Prigge and Others v. Deutsche Lufthansa AG, [2011] ECR I-08003, Rec 14

47. Ibid., $\operatorname{Rec} 63$.

48. Ibid., Rec 75-6. 
ble, because, in general, the CJEU is very lenient in accepting an aim as legitimate, ${ }^{49}$ especially when it is set by social partners. ${ }^{50}$ In Prigge the CJEU considered it too wide a stretch to accept 'air traffic security' as an aim related to employment policy, the labour market or vocational training. ${ }^{51}$ It seems that in this case the CJEU followed a more typical anti-discriminatory approach.

In Petersen ${ }^{52}$ the CJEU considered that sixty-eight 'may be regarded as sufficiently high to serve as the endpoint [...]. ${ }^{53}$ Furthermore, unlike in Prigge the measure could be justified by a number of legitimate aims that were not related to the capacity of the person to perform the profession. ${ }^{54}$ For example, consideration was given to the situation of the (regional) labour market and control of the public health sector expenditure. ${ }^{55}$ These reflect considerations that fit with the complete life view.

The second case in which the CJEU concluded that the national measure would be precluded by the FED is Commission v. Hungary. ${ }^{56}$ The challenged legislation lowers the age of mandatory retirement from seventy to sixty-two for judges, prosecutors and notaries. The aim of the legislation is, first, to standardise the rules relating to retirement for all persons and, second, to facilitate the entry of young lawyers into the judicial system with a view to establishing a 'balanced age structure'. ${ }^{57}$ The Court, following its previous case law in granting Member States a broad margin of discretion in defining legitimate aims, considers both as a legitimate aim falling within the scope of Article 6 FED. ${ }^{58}$ However, the Court finds the measure to be not necessary since it does not take into account the interests of the persons affected by the measure because the transposition period allows them ample time to prepare to leave office. ${ }^{59}$ This is very clearly a fair innings argument.

All other cases were considered not to be precluded by the FED. These cases share the commonality that, in general, the national measures took into account the situation of older workers, either by providing them with a choice to retire or to continue to work after retirement age $\mathrm{e}^{60}$ or by taking into account the labour market situation. ${ }^{61}$ Most importantly, it was considered by the CJEU that the workers were entitled to alterna-

49. Cf. B.P. ter Haar, 'EU Age Discrimination Law: A Curse of a Blessing for EU Youth Policy', in U. Belavusau and K. Henrard (eds.), EU Anti-Discrimination Law Beyond Gender (2018) 295, at 306. See also: Case 411/05 Félix Palacios de la Villa v. Cortefiel Servicios SA, [2007] ECR I-08531, Rec 68.

50. Odar, above n. 44, $\operatorname{Rec} 47$, with reference to Case 141/11 Torsten Hörnfeldt v. Posten Meddelande AB ECLI:EU:C:2012:421, Rec 32.

51. Prigge, above n. 46, Rec 81-2.

52. Case 341/08 Domnica Petersen v. Berufungsausschuss für Zahnärzte für den Bezirk Westfalen-Lippe, [2010] ECR I-47.

53. Ibid., Rec 52 .

54. Ibid., $\operatorname{Rec} 78$

55. Ibid., Rec 63 and 72-3.

56. Commission v. Hungary, above n. 21.

57. Ibid, Rec 28-31.

58. Ibid., $\operatorname{Rec} 61-63$

59. Ibid., $\operatorname{Rec} 72$

60. Joined cases 159/10 and 160/10 Gerhard Fuchs and Peter Köhler v. Land Hessen, [2011] ECR I-06919; and Hörnfeldt, above n. 50.

61. Petersen, above n. 52 tive income, i.e. old-age pensions. ${ }^{62}$ What is of concern is not the exact amount of the pension but having access to an alternative income. ${ }^{63}$ Other than some of the cases addressed previously, ${ }^{64}$ in these cases there were no issues of unequal treatment with respect to the alternative income that would put these workers at a disadvantage compared with other workers of the same age group. All this reflects a complete life view, especially the fact that there is an acceptance that there is an end to working life and that this is acceptable for as long as the worker has been able to maximise his welfare, i.e. to the same pension as he would have received without the measure.

\subsection{Analysis of the Cases in the Category 'Young'}

As already established in Section 3, quantitatively, out of the seven cases in this category, only two cases were considered to be precluded by the FED, whereas the other five cases were not to be precluded.

One of the cases not to be precluded by the FED is the case $O .{ }^{65}$ The CJEU dismissed this case as being nondiscriminatory, because the young person, $\mathrm{O}$, was not in a comparable insecure employment position after the expiry of his fixed-term contract as other, older, workers. ${ }^{66}$ Another case the CJEU found not to be precluded by the FED is Abercrombie, ${ }^{67}$ which deals with the use of on-call contracts for young people up to the age of twenty-five, after which the contract is automatically terminated. The legitimate aim underpinning the Italian measure is to create a situation in which employers are encouraged to hire young persons in order to offer them opportunities to gain work experience that would create a springboard for young people to new, more permanent, employment opportunities. ${ }^{68}$ The CJEU was sympathetic to the arguments of the Italian Government that such a measure is necessitated by persistent economic crisis and weak growth. ${ }^{69}$ Moreover, the Court considered that being employed and gaining work experience is preferable over being unemployed when the flexibility of on-call contracts would not be offered. Hence, the Court concluded that the measure would not be precluded by the FED. ${ }^{70}$ The arguments in both these cases reflect a typical fair innings argument approach.

62. Palacios de la Villa, above n. 49; Case 388/07 The Queen, on the application of The Incorporated Trustees of the National Council for Ageing (Age Concern England) v. Secretary of State for Business, Enterprise and Regulatory Reform, [2009] ECR I-01569; Case 45/09 Gisela Rosenbladt v. Oellerking Gebäudereinigungsges. mbH, [2010] ECR I-09391; Fuchs \& Köhler, above n. 60; and Hörnfeldt, above n. 50.

63. Palacios de la Villa, above n. 51, Rec 73; and Rosenbladt, above n. 62, Rec 73-76.

64. Especially the Danish cases Ingeniørforeningen i Danmark, above n. 43, Dansk jurist, above n. 44, and Rasmussen, above n. 43.

65. Case 432/14 O v. Bio Philippe Auguste SARL ECLI:EU:C:2015:643

66. Ibid., $\operatorname{Rec} 35$

67. Case 143/16 Abercrombie \& Fitch Italia Srl v. Antonino Bordonaro ECLI:EU:C:2017:566.

68. Ibid., Rec 33-4

69. Ibid., $\operatorname{Rec} 42$

70. Ibid., Rec 47 
The remaining five cases in this category deal with (some form of advancement in) pay grades often in relation to the calculation of years of experience. The rulings of the CJEU in these cases vary with two cases to be found as being precluded by the FED and three cases not being precluded (see Table 1). From the cases, in the latter group Lesar ${ }^{71}$ is rather comparable to Parris since it concerned an issue of fixing an age for admission or entitlement to a pension scheme. In Lesar, unlike in Parris, access to the pension scheme is directly based on age, which results in a disadvantageous treatment of young people. ${ }^{72}$ However, as in Parris, the difference in treatment falls within the exception covered by paragraph 2 of Article 6 FED. ${ }^{73}$

The other two cases, Escribano Vindel ${ }^{74}$ and Horgan E Keegan ${ }^{75}$ are rather similar and seem rather typical for the financial crisis of 2008, which forced a number of EU Member States to make major financial cutbacks in the public sector. ${ }^{76}$ Both deal with a lowering of the pay grade of judiciaries and of teachers, respectively. In Escribano Vindel it was argued that the measure affected young judiciaries more than older. However, following the arguments of the Spanish government, ${ }^{77}$ the CJEU concluded that there was no issue of age discrimination, firstly, because the position of 'ordinary' judge is open for persons up to the age of retirement And, secondly, because there exists no obligation to move to higher judiciary positions. Moreover the Court found no evidence that a certain age group is more affected by the measure than other groups; neither by age nor by length of service. ${ }^{78}$ In Horgan $\mathcal{E}$ Keegan the challenged Irish law reduced the pay by $10 \%$ for all new entrants into the public service, including newly appointed teachers, on or after 1 January $2011 .^{79}$ Even though it was clear that the majority of the new recruits were younger than twenty-five, the CJEU found that the date of 1 January 2011 as a distinguishing criterion is neither inextricably nor indirectly linked to age - especially since the age profile of the cohort of new entrance did not differ much from the cohort of entrance before the regime change. ${ }^{80}$ The Court's reasoning in Escribano Vindel

71. Case 159/15, Franz Lesar v. Beim Vorstand der Telekom Austria AG eingerichtetes Personalamt ECLI:EU:C:2016:451

72. Ibid., Rec 21, with reference to Hütter, above n. 15, Rec 38.

73. Lesar, above n. 71, Rec 31.

74. Case 49/18 Carlos Escribano Vindel v. Ministerio de Justicia ECLI:EU:C:2019:106.

75. Case 154/18 Tomás Horgan and Claire Keegan v. Minister for Education \& Skills and Others ECLI:EU:C:2019:113.

76. See in general: special issue of the Industrial Law Journal, 41(3) (2012); and F. Vandenbroucke, C. Barnard \& G. De Baere (eds.), A European Social Union after the Crisis (2017). More specifically related to the cases addressed here, among others: A. Baylos and F. Trillo, 'Social Dimension of European Union and the Situation of the Labour Law in the Member States: Evaluation of the Spanish Experience', Revista de Evaluación de Programas y Políticas Públicas Num 154 (2013); and E. Achtsioglou and M. Doherty, 'There Must Be Some Way Out of Here: The Crisis, Labour Rights and Member States in the Eye of the Storm', 20 European Labour Law Journal 219 (2014).

77. Escribano Vindel, above n. 74, Rec 76.

78. Ibid., Rec 49, 56 and 58.

79. Horgan \& Keegan, above n. 75, Rec 5.

80. Ibid., Rec 26. reflects a complete life view. In Horgan E Keegan it is not really possible to distinguish a certain approach, if any it could be the complete life view, since there is clearly no link to the fair innings argument, nor is there any sign of consideration of the harm the measure may cause for the young workers affected by the measure.

A commonality in the remaining two cases in this category, Kücükdeveci ${ }^{81}$ and Hütter ${ }^{82}$ is that age is used as a determinant in the calculation of years of service - in Kücükdeveci to determine the notice period and in Hütter to exclude years of work experience gained before the age of eighteen. Another thing they have in common is that the national measures resulted in a difference in treatment between persons in the same age group. More particularly, the measure in Kücükdeveci served several aims, such as a longer notice period for workers over forty, a progressive extension of the notice period for all workers, and an age threshold of twenty-five in order to give employers a relief from lengthy notice periods for young workers. ${ }^{83}$ The underlying idea was that younger workers are more flexible in finding new employment and therefore would not need lengthy notice periods and that a shorter notice period for younger workers would facilitate their recruitment as employers would be more willing to hire them. ${ }^{84}$ While the measure serves a legitimate aim covered by Article 6 FED, the CJEU found it inappropriate since it would result in unequal treatment between young workers, in that those who entered the labour market at a young age would be disadvantaged compared with those who entered the labour market at an older age. ${ }^{85}$ The measure in Hütter excluded work experience gained before the age of eighteen. Given the educational system in Austria, this would mean that students who gained work experience during an apprenticeship before the age of eighteen would not count, whereas it would count when the apprenticeship was taken after the age of eighteen. At what age the apprenticeship was done depended on the type of education chosen: vocational training or secondary education. The measure thus resulted in unequal treatment between young people based on the type of education, i.e. secondary education or vocational training. Consequently, the measure would negatively influence their starting position on the labour market. In both cases, thus, the CJEU concluded that the effect of the measure was that the disadvantaged group would be permanently be excluded from future opportunities, resulting in substantive inequality within the same age group. This reflects the fair innings argument.

\subsection{Analysis of the Cases in Category 'Other'}

Many of the cases in this category are related to the CJEU's ruling in Hütter, which resulted in adjustments of several measures, especially in Austria and Germa-

81. Case 555/07 Seda Kücükdeveci v. Swedex GmbH \& Co. KG, [2010] ECR I- 00365.

82. Hütter, above n. 15

83. Kücükdeveci, above n. 81, Rec 34.

84. Ibid., $\operatorname{Rec} 39$

85. Ibid., Rec 42 
ny. ${ }^{86}$ As briefly addressed in Section 3 , these cases cannot be linked to a particular age category because it concerns transitional legislation that aims to correct a previously discriminatory measure. What these measures have in common is that they aim to protect the acquired rights and legitimate expectations of workers that were favoured under the previously discriminatory legislation. This from the principle that changes in the legislation to correct a wrongdoing should not be to the detriment of the workers who were previously not in a disadvantaged position. ${ }^{87}$ To illustrate the reasoning of the CJEU in these cases, two cases will be addressed in more detail: Schmitzer ${ }^{88}$ and Specht e.o. ${ }^{89}$

Schmitzer concerns an Austrian transitional measure that purported to serve several aims: objectives of procedural economy, respect for acquired rights and the protection of legitimate expectations, and budgetary constraints. ${ }^{90}$ With respect to the last aim, the CJEU referred to its judgment in Fuchs \& Köhler ${ }^{91}$ and argued that, similarly to private businesses, budgetary issues of administrative nature 'cannot in themselves constitute a legitimate aim within the meaning of Article $6(1)$ of Directive $2000 / 78,{ }^{92}$ With regard to the acquired rights and the protection of the legitimate expectations, the Court considered that these could constitute a legitimate aim that can justify the maintenance of different treatment in a transitional period. ${ }^{93}$ However, even though the measure in this case preserves the acquired rights and legitimate expectations of the civil servants who will not be subject to the new advancement rules (especially the five-year period for the first advancement instead of two years under the previous rules), it cannot justify a measure that maintains the age-based difference in treatment. ${ }^{94}$ Such a measure is not appropriate for the purpose of establishing a non-discriminatory system for civil servants who were disadvantaged by that previous system?. ${ }^{95}$

In Specht e.o. the CJEU had to consider national legislation that introduced a new remuneration system for civil

86. E.g. Case 24/17 Österreichischer Gewerkschaftsbund, Gewerkschaft Öffentlicher Dienst v. Republik Österreich ECLI:EU:C:2019:373, Rec 11.

87. Cf. Joined Cases 501/12 to 506/12, 540/12 and 541/12 Thomas Specht and Others v. Land Berlin and Bundesrepublik Deutschland ECLI:EU:C:2014:2005, Rec 64, with reference to Case 456/05 Commission v. Germany ECLI:EU:C:2007:775, Rec 63.

88. Case 530/13 Leopold Schmitzer v. Bundesministerin für Inneres ECLI:EU:C:2014:2359.

89. Specht a.o., above n. 87

90. Schmitzer, above n. 88, Rec 39 and 40.

91. Fuchs \& Köhler, above n. 62, Rec 73-4.

92. Schmitzer, above $n .88, \operatorname{Rec} 41$.

93. Schmitzer, above $n$. 88, Rec 42, with reference to joined cases $297 / 10$ and 298/10 Hennings and Mai ECLI:EU:C:2011:560, Rec 90-1.

94. Owing to the change in the period for first advancement from two years to five years, civil servants who were disadvantaged under the previous system and who opted for a reassessment of their advancement under the new system would again be discriminated against in relation to the favoured group because the first advancement period for the disadvantaged civil servants would be three years longer, putting them again at a disadvantage compared with the same group of civil servants.

95. Schmitzer, above n. 88, $\operatorname{Rec} 44$. servants to correct a previously discriminatory wrong. The starting point for further advancement within the new system, however, was based solely on the amount of pay under the old system. Consequently, the civil servants that were treated less favourably by the previous system would start at a disadvantage in the new system. The new system compensates partly for the disadvantage because all civil servants would be entitled to one additional (transitional) step based on which they would then be placed into the new pay step that corresponds the closest with an additional round-up of the pay to that step. Although this means an advancement for all civil servants, the effect of the previous discriminatory rule is not neutralised completely. ${ }^{96}$ Similarly to Schmitzer, the Court acknowledged that preserving acquired rights can be a legitimate aim as an 'overriding reason in the public interest. ${ }^{97}$ Moreover, the CJEU found the measure appropriate also because without it many civil servants would have incurred a loss in salary equivalent to one step (i.e. $80-150$ EURO). ${ }^{98}$ The Court also considers the measure necessary, among other reasons, because of the administrative burden if, retrospectively, the position of every civil servant would have to be reviewed individually. Second, for as far as there would still be some differences, these would fade away after a few years since the transitional measure provided in a more favourable repositioning in the wage-scale. ${ }^{99}$

What we can get from these two cases is that the CJEU is sensitive to the argument that the transitional measure aims to preserve acquired rights by those that were favoured by the previous measure. Therefore, the transitional measure does not have to completely neutralise the discriminatory effect of the previous measure (Specht e.o.); however, there is a margin that needs to be observed. In Schmitzer the transitional measure clearly exceeded that margin, since it maintained the difference in treatment on the grounds of age, and, moreover, it actually created a new difference of treatment that could directly be related to age. Since these cases are based on the Hütter ruling, in which the Court clearly reflected a fair innings argument, the same is found here: it is all about creating substantive equality in order to provide all persons with equal opportunities in working life.

The cases $P_{0 h} l^{100}$ and Starjakob ${ }^{101}$ are also related to Hütter since they too deal with transitional national measures to correct a previously unjustifiable discriminatory measure. The issue addressed in these cases, however, is not the correcting measure itself, but the periodic limitations to reassess accrediting periods for

96. Specht a.o., above n. 88 , Rec 53-8

97. Ibid., Rec 64, with reference to Case 456/05 Commission v. Germany ECLI:EU:C:2007:755, Rec 63 and Hennings and Mai, above n. 93, Rec 90.

98. Specht a.o., above n. 88, Rec 65-7

99. Ibid, Rec 80-3.

100. Case 429/12 Siegfried Pohl v. ÖBB Infrastruktur AG ECLI:EU:C: 2014:12.

101. Case 417/13 ÖBB Personenverkehr AG v. Gotthard Starjakob ECLI:EU:C:2015:38. This case also dealt with a newly adopted measure that aimed to right a previously unjustifiable discriminatory measure. The newly adopted measure was found discriminatory as well. 
advancement. Pohl's request for a reassessment of his periods of service that should have been taken into account for his advancement on the salary scale was refused because the statutory period of thirty years starting from the moment the employment contract commenced had elapsed. The CJEU clarified that whether the starting point of a limitation period would be changed was a matter for national law and that

the fact that the Court may have ruled that the breach of European Union law has occurred generally does not affect the point at which that period starts to run. ${ }^{102}$

The Court repeated this in Starjakob. ${ }^{103}$ Again, since these cases are about creating substantive equality by correcting the effects of a previously discriminatory measure, these fit with the fair innings argument.

The remaining three cases in this category are not related to Hütter. Tyrolean Airmays ${ }^{104}$ and Bomman ${ }^{105}$ show similarities in that both deal with lengths of service and experience rather than a particular age group. In Tyrolean Airmays this became an issue because workers with similar length of work experience were treated differently, the only experience taken into account for advancement being that gained in employment with Tyrolean Airways. This would put experienced cabin crew members who previously worked for Austrian Airlines or Lauda Air in a disadvantaged position; hence it indirectly discriminates older workers. ${ }^{106}$ The CJEU considered that even though the challenged measure falls within the scope of the directive, ${ }^{107}$ it does not constitute discrimination on grounds of age, since the differential treatment is based purely on the date of recruitment. ${ }^{108}$ The fact that work experience is not taken into account at the moment the employment contract commences is not related to age. ${ }^{109}$ It applies to everyone who starts to work for Tyrolean Airlines, irrespective of whether someone is young, old or middleaged. No distinction by age, direct or indirect, means no age discrimination. In Bomman the CJEU also concluded that there is no issue of age discrimination since

the inclusion of periods of school education and the extension of the period for advancement within the first step of the salary scheme, applies in the same way to all workers who make a request for such inclu-

102. Pohl, above n. 100, Rec 31, with reference to Joint Cases $89 / 10$ and 96/10 Q-Beef NV v. Belgische Staat and Frans Bosschaert v. Belgische Staat, Vleesgroothandel Georges Goossens en Zonen NV and Slachthuizen Goossens NV, [2011] ECR I-07819, Rec 48

103. Starjakob, above n. 101, Rec 59-75.

104. Case 132/11 Tyrolean Airways Tiroler Luftfahrt Gesellschaft mbH v. Betriebsrat Bord der Tyrolean Airways Tiroler Luftfahrt Gesellschaft $m b H$ ECLI:EU:C:2012:329.

105. Case 539/15, Daniel Bowman v. Pensionsversicherungsanstalt ECLI:EU:C:2016:977.

106. Tyrolean Airways, above n. 104, Rec 20, preliminary question 1 .

107. Ibid., Rec 24 .

108. Ibid., $\operatorname{Rec} 29$

109. Ibid. sion, including, retroactively, workers who have already reached higher steps. ${ }^{110}$

These rulings reflect again a more complete life view since they reflect a rather egalitarian appreciation of the measures.

Differing completely from any of the previous cases in this category is Bartsch, ${ }^{111}$ which deals with an issue of 'relative' age, meaning that there exists an age requirement in legislation not defined by an absolute age but by age related to the age of another person. More concretely, the measure in Bartsch stipulated that widower pensions would not be paid if 'the widow/widower is more than 15 years younger than the former employee'.112 Unfortunately, at the time the facts of the case took place and the case was brought to court, the implementation period for the FED had not expired yet, and the CJEU therefore found the case inadmissible and gave no ruling. ${ }^{113}$

\subsection{Analysis of the Cases in the Category 'Middle-Aged'}

The last category to address is 'middle-aged'. What links these cases is that all national measures set a maximum age, owing to which older workers are denied access either to education/training or employment. Often the age limit lies around thirty or thirty-five; hence the classification as middle-aged.

In this group the CJEU found only the national measure in Vital Pérez ${ }^{114}$ to be excluded by the FED (see Table 1). The measure fixes a maximum age of thirty for recruitment of local police officers. It could be considered as a genuine job requirement within the meaning of Article 4(1) FED, given the particular physical capacities needed for the job, ${ }^{115}$ but, given the fact that there is no need to maintain a particular age structure within the police service ${ }^{116}$ and that the physical requirements are not 'exceptionally high', ${ }^{117}$ the CJEU concluded that the age requirement cannot appropriately be justified as a genuine job requirement. ${ }^{118}$ Secondly, the CJEU considered whether the measure could be justified by Article 6(1) FED. As a legitimate aim, the referring court pointed out that the age limit was related to training requirements for the post in question and 'the need for a reasonable period of employment before retirement or transfer to another activity'. ${ }^{119}$ However, as no (concrete enough) evidence has been presented to support the measure in the main proceedings as appropriate or nec-

110. Bowman, above n. 105, Rec 31 .

111. Case 427/06, Birgit Bartsch v. Bosch und Siemens Hausgeräte (BSH) Altersfürsorge $\mathrm{GmbH}$, [2008] ECR I- 07425.

112. Ibid., $\operatorname{Rec} 7$

113. Ibid., Rec 17 and 25.

114. Case 416/13 Mario Vital Pérez v. Ayuntamiento de Oviedo ECLI:EU:C: 2014:2371

115. Ibid., Rec 37 and 41, with reference to Prigge, above n. 46, Rec 67; and Wolf (case 229/08, ECLI:EU:C:2010:3), Rec 41

116. Vital Pérez, above n. $114, \operatorname{Rec} 56$.

117. Ibid., Rec 54

118. Ibid., Rec 57

119. Ibid., $\operatorname{Rec} 64$ 
essary to achieve that aim, the CJEU indicated that such a measure could not be justified by Article 6(1) FED. ${ }^{120}$ In Salaberria Sorondo, ${ }^{121}$ a similar measure as the one in Vital Peréz was challenged; however, the facts were different, resulting in the outcome that the age requirement constituted indeed a justifiable genuine job requirement. ${ }^{122}$ The CJEU considered that the measure was much better substantiated with statistical evidence, in particular the need for '(re-)establishing a satisfactory age pyramid', which ought to be taken dynamically, that is with a view to the future. ${ }^{123}$ Secondly, the Court considered that the functions were different in that for the latter young recruits would be assigned the physically most demanding jobs. ${ }^{124}$ With reference to Wolf, in which case the measure set an age limit (of thirty) for the recruitment of firefighters, ${ }^{125}$ the CJEU acknowledged that when physical requirements are 'exceptionally high' it is clear that these can be performed only by young workers. ${ }^{126}$ Furthermore, the CJEU acknowledged that to ensure the efficient functioning of the fire service it may be necessary that the majority of the workers are younger than forty-five or fifty. In this light, the CJEU argued that the age at which a fire fighter is recruited determines how long he will be able to perform the job. ${ }^{127}$ Hence, under such conditions an age limit can be considered as a genuine job requirement. ${ }^{128}$ The Court's reasoning in these cases comes closest to a more typical anti-discriminatory approach

The last case in this category, De Lange, ${ }^{129}$ deals with an income tax measure that allows full reduction of vocational training costs for persons under thirty and limits this to the amount of 15,000 EURO for persons older than thirty. The measure aims to make it more attractive for young persons to pursue vocational training in order to improve their position in the labour market, which qualifies as a legitimate aim under Article 6(1) FED. ${ }^{130}$ Moreover, the CJEU found the measure appropriate and necessary, since, as argued by the Dutch government, in general persons over the age of thirty have

had the opportunity to undertake prior training and to pursue a professional activity, with the result that, being in a better financial position than young people who have recently left the school system, they are able to bear at least in part the financial burden of new training. ${ }^{131}$

\footnotetext{
120. Ibid., Rec 70-3.

121. Case 258/15 Gorka Salaberria Sorondo v. Academia Vasca de Policía y Emergencias ECLI:EU:C:2016:873.

122. Ibid., Rec 50.

123. Ibid., $\operatorname{Rec} 47$

124. Ibid., Rec 46.

125. Wolf, above n. 115

126. Ibid., $\operatorname{Rec} 41$

127. Ibid., $\operatorname{Rec} 43$

128. Ibid., $\operatorname{Rec} 45$

129. Case 548/15 J.J. De Lange v. Staatssecretaris van Financiën ECLI:EU:C: 2016:850.

130. Ibid., $\operatorname{Rec} 29$
}

This is very clearly a fair innings argument.

\section{Evaluation and Conclusions}

In this section I evaluate the reasoning of the CJEU against the background of the theoretical approaches presented in Section 2, i.e. complete life view, fair innings argument and a more typical anti-discriminatory approach. For this evaluation it is important to understand, in general, the arguments of the CJEU in deciding that a measure would or would not be precluded by the FED. The analysis of this is summarised in Table 3 .

Click here for a PDF-version of Table 3.

A number of conclusions can be drawn from this table: First, a good number of cases are not precluded by the FED because they do not deal with age discrimination $(P o h l)$, fall outside the scope of the directive (Bartsch), are not an issue of age discrimination (Florescu, $S C M D$, Escribano Vindel, Horgan and Keegan, Tyrolean Airmays, and Bomman) or fall within the exception of Article 6(2) FED (Parris and Lesar). Second, a few reasons for preclusion or not are reflective of each other. These are as follows:

- age is indirectly involved because it is connected to the length of service that is taken as a differentiating criterion (HK Denmark, Kleinsteuber) versus age directly and as a sole differentiating criterion (Mangold);

- age as genuine job requirement/balanced age structure being appropriate and necessary (Wolf, Salaberria Sorondo, Fuchs E Köhler) versus not being appropriate and necessary (Prigge, Vital Peréz); and - sufficient (Hennings and Mai, Specht e.o., Stollwitzer, Unland, and Österreichischer Gemerkschaftsbund) versus insufficient (Starjakob, Schmitzer, and Leitner) neutralisation of the effect of a previously discriminatory measure.

Furthermore, this table clearly shows that some reasons are more typical of a certain age category, e.g. whether there is access to an alternative source of income seems to be typical of older workers, and the sufficient neutralisation of a previously discriminatory measure is typical of the category 'other'.

In Table 4 the arguments of the CJEU have been related to the theoretical approaches. Indications on this have already been given in Section 4; the table merely summarises it.

Click here for a PDF-version of Table 4.

131. Ibid., $\operatorname{Rec} 33$ 
Table 3 Summarised analysis of the CFEU's arguments in cases on age discrimination

\begin{tabular}{|c|c|c|c|c|c|c|c|c|c|}
\hline $\begin{array}{l}\text { Reasons not } \\
\text { precluded }\end{array}$ & Old & Yng & $M$ & Other & $\begin{array}{l}\text { Reasons preclu- } \\
\text { ded }\end{array}$ & Old & Yng & $M$ & Other \\
\hline $\begin{array}{l}\text { Not in scope / } \\
\text { not on age }\end{array}$ & C & & & $\begin{array}{l}\text { Bartch; } \\
\text { Pohl }\end{array}$ & & & & & \\
\hline $\begin{array}{l}\text { No discrimi- } \\
\text { nation on } \\
\text { grounds of age }\end{array}$ & $\begin{array}{l}\text { SCMD; } \\
\text { Florescu }\end{array}$ & $\begin{array}{l}\text { O; Escri- } \\
\text { bano } \\
\text { Vindel; } \\
\text { Horgan } \\
\text { \& Kee- } \\
\text { gan }\end{array}$ & & $\begin{array}{l}\text { Tyrolean } \\
\text { airlines; } \\
\text { Bowman }\end{array}$ & & & & & \\
\hline $\begin{array}{l}\text { Exception Art. } \\
6(2) \text { FED }\end{array}$ & Parris & Lesar & & & & & & & \\
\hline $\begin{array}{l}\text { Access alterna- } \\
\text { tive income / } \\
\text { income security }\end{array}$ & $\begin{array}{l}\text { Palacios } \\
\text { de la Vil- } \\
\text { la; Age } \\
\text { Concern; } \\
\text { Rose- } \\
\text { nbladt; } \\
\text { Geor- } \\
\text { giev; } \\
\text { Hörn- } \\
\text { veldt; } \\
\text { Huber- } \\
\text { tus; } \\
\text { Odar; } \\
\text { Tekniq }\end{array}$ & $\begin{array}{l}\text { Horgan } \\
\text { and Kee- } \\
\text { gan }\end{array}$ & & & $\begin{array}{l}\text { Reduction in } \\
\text { (alternative) } \\
\text { income / } \\
\text { interest persons } \\
\text { not sufficiently } \\
\text { taken into } \\
\text { account }\end{array}$ & $\begin{array}{l}\text { Ingeniørf } \\
\text { orenin- } \\
\text { gen i } \\
\text { Dan- } \\
\text { mark; } \\
\text { Rasmus- } \\
\text { sen; } \\
\text { Dansk } \\
\text { Jurist; } \\
\text { Commis- } \\
\text { sion v } \\
\text { Hungary }\end{array}$ & & & \\
\hline $\begin{array}{l}\text { Labour market } \\
\text { situation taken } \\
\text { into account }\end{array}$ & $\begin{array}{l}\text { Petersen; } \\
\text { Felber }\end{array}$ & $\begin{array}{l}\text { Aber- } \\
\text { crombie }\end{array}$ & De Lange & & $\begin{array}{l}\text { Measure results } \\
\text { in unequal } \\
\text { treatment of } \\
\text { persons in same } \\
\text { age group }\end{array}$ & & $\begin{array}{l}\text { Kücükde- } \\
\text { veci; } \\
\text { Hütter }\end{array}$ & & \\
\hline $\begin{array}{l}\text { Age indirectly - } \\
\text { length of ser- } \\
\text { vice (pro rata } \\
\text { temporis) }\end{array}$ & $\begin{array}{l}\text { HK Den- } \\
\text { mark; } \\
\text { Klein- } \\
\text { steuber }\end{array}$ & & & & $\begin{array}{l}\text { Age sole criteri- } \\
\text { on }\end{array}$ & Mangold & & & \\
\hline $\begin{array}{l}\text { Age as job } \\
\text { requirement / } \\
\text { balanced age } \\
\text { structure }\end{array}$ & $\begin{array}{l}\text { Fuchs \& } \\
\text { Köhler; } \\
\text { Werner } \\
\text { Fries }\end{array}$ & & $\begin{array}{l}\text { Wolf; } \\
\text { Salaber- } \\
\text { ria Sor- } \\
\text { ondo }\end{array}$ & & $\begin{array}{l}\text { Age as job } \\
\text { requirement is } \\
\text { inappropriate }\end{array}$ & Prigge & & $\begin{array}{l}\text { Vital Pér- } \\
\text { ez }\end{array}$ & \\
\hline $\begin{array}{l}\text { Sufficient neu- } \\
\text { tralisation previ- } \\
\text { ously discrimi- } \\
\text { natory effect, } \\
\text { incl. protection } \\
\text { established } \\
\text { advantages }\end{array}$ & & & & $\begin{array}{l}\text { Hennings } \\
\text { \& May; } \\
\text { Specht } \\
\text { e.o.; } \\
\text { Stollwit- } \\
\text { zer; } \\
\text { Unland; } \\
\text { Österrei- } \\
\text { chischer } \\
\text { Gewerk- } \\
\text { schafts- } \\
\text { bund }\end{array}$ & $\begin{array}{l}\text { Insufficient neu- } \\
\text { tralisation previ- } \\
\text { ously discrimi- } \\
\text { natory effect }\end{array}$ & & & & $\begin{array}{l}\text { Starjakob; } \\
\text { Schmit- } \\
\text { zer; Leit- } \\
\text { ner }\end{array}$ \\
\hline
\end{tabular}




\begin{tabular}{|c|c|c|c|c|c|c|c|c|}
\hline & \multicolumn{4}{|c|}{ Not Precluded } & \multicolumn{4}{|l|}{ Precluded } \\
\hline & Old & Young & $\begin{array}{l}\text { Middle- } \\
\text { aged }\end{array}$ & Other & Old & Young & $\begin{array}{l}\text { Middle- } \\
\text { aged }\end{array}$ & Other \\
\hline Complete life view & $\begin{array}{l}\text { Palacios } \\
\text { de la Villa; } \\
\text { Age Con- } \\
\text { cern; } \\
\text { Hubertus; } \\
\text { Petersen; } \\
\text { Klein- } \\
\text { steuber; } \\
\text { Rose- } \\
\text { nbladt; } \\
\text { Hörnveldt; } \\
\text { Odar; HK } \\
\text { Denmark; } \\
\text { Ingeniørfo } \\
\text { reningen i } \\
\text { Danmark } \\
\text { v Tekniq; } \\
\text { Felber; } \\
\text { Parris; }\end{array}$ & $\begin{array}{l}\text { Lesar; } \\
\text { Escribano } \\
\text { Vindel; } \\
\text { Horgan } \\
\text { and Kee- } \\
\text { gan }\end{array}$ & & $\begin{array}{l}\text { Tyrolean } \\
\text { Airlines; } \\
\text { Bowman }\end{array}$ & $\begin{array}{l}\text { Mangold; } \\
\text { Ingeniørfo } \\
\text { reningen i } \\
\text { Danmark; } \\
\text { Rasmus- } \\
\text { sen; Dansk } \\
\text { Jurist }\end{array}$ & & & \\
\hline Fair innings argument & $\begin{array}{l}\text { Georgiev; } \\
\text { Fuchs \& } \\
\text { Kohler; } \\
\text { Florescu; } \\
\text { SCMD }\end{array}$ & $\begin{array}{l}\text { O; Aber- } \\
\text { crombie }\end{array}$ & De Lange & $\begin{array}{l}\text { Pohl; Hen- } \\
\text { nings \& } \\
\text { May; } \\
\text { Specht } \\
\text { e.o.; } \\
\text { Unland; } \\
\text { Stollwit- } \\
\text { zer; Öster- } \\
\text { reichischer } \\
\text { Gewerk- } \\
\text { schafts- } \\
\text { bund }\end{array}$ & $\begin{array}{l}\text { Commis- } \\
\text { sion v } \\
\text { Hungary }\end{array}$ & $\begin{array}{l}\text { Hütter; } \\
\text { Kücükde- } \\
\text { veci }\end{array}$ & & $\begin{array}{l}\text { Starjakob; } \\
\text { Schmitzer; } \\
\text { Leitner }\end{array}$ \\
\hline $\begin{array}{l}\text { Traditional anti-discr. } \\
\text { approach }\end{array}$ & $\begin{array}{l}\text { Werner } \\
\text { Fries }\end{array}$ & & $\begin{array}{l}\text { Salaberria } \\
\text { Sorondo; } \\
\text { Wolf }\end{array}$ & & Prigge & & Vital Pérez & \\
\hline
\end{tabular}

NB: The cases $C$ and Bartch are not in this table because the CJEU did not consider them on their merits.

What stands out from this table is that many measures (twelve out of sixteen) treating older workers less favourably have not been precluded by the FED, whereas only four of them have been precluded. The contrast becomes even stronger when we realise that the three cases in the age category 'young' that reflect a complete life view approach either did not constitute age discrimination because something else was found (more) distinctive (Escribano Vindel; Horgan and Keegan) or fall under the exception of Article 6(2) FED (Lesar). In absolute numbers it means that older persons have had to accept disadvantageous treatment more often than younger persons.

When evaluating the cases that seem to reflect the fair innings argument the CJEU seems to favour the posi- tion of young workers over that of older workers. This is the situation in cases affecting young people, as well as middle-aged and old people. While in Hütter it was an issue of unequal treatment within the age category 'young', in Kücükdeveci it was an intergenerational matter that provided stronger protection for older workers than younger workers and was found by the CJEU to be precluded by the FED. In the cases Georgiev and Fuchs $\mathcal{E}$ Kohler the situation was reversed since the measures that were challenged aimed to improve the position of young persons at the cost of older persons who had already had their chances. The same is true for $D e$ Lange with regard to access to education: the challenged tax measure favoured people under the age of thirty, since people older than thirty were presumed to have 
had chances to study and gather more resources to pay for their education. Add to this the cases Wolf and Salaberria Sorondo, both setting an age limit with respect to access to employment, and the picture of young people being favoured over older people in the CJEU's case law becomes even more resilient.

What we get is what I have already indicated at the beginning of the paper as being a toxic combination: under the complete life view more measures have been accepted that negatively affect old people rather than young people; and under the fair innings argument more measures have been accepted that positively affect young people to the detriment of middle-aged and old people. The overall image of this combination is that the CJEU is more lenient in accepting disadvantageous measures for older people and more strict in protecting young people. Thus, while the relative numbers of measures that the CJEU found to be precluded by the FED do not indicate a significant difference in treatment between young and old, the reflective evaluation of the CJEU's rulings based on the theoretical approaches, especially the complete life view and fair innings argument, does indicate a significant difference. Maybe the CJEU is not aware of its bias, but by not having made a clear choice on how to evaluate age discrimination cases, a practice of unequal treatment has grown. The conclusion is, therefore, that the CJEU indeed discriminates in age discrimination cases. 